\title{
Establishing Action Thresholds for Control of Cankerworms in Regina, Saskatchewan, Canada
}

\author{
Russell Eirich
}

\begin{abstract}
An action threshold (AT) is often established to determine if and when control treatments are required for pest populations. In municipal settings, control treatments for insects defoliating the urban forest are typically determined in response to customer requests, maintenance demands of highly visible municipal public spaces, economic requirements, and actual insect damage. In 2006, the City of Regina Integrated Pest Management section created a new method of establishing an AT for cankerworm control by determining if monitoring counts for female cankerworms (Paleacrita vernata Peck and Alsophila pometria L.) were greater than $95 \%$ of an identified "normal" population range when based on historical records.

Key Words. Acer; action threshold; Alsophila pometria; defoliation; empiric rule; Fraxinus spp.; Geometridae; Lepidoptera; Paleacrita vernata; Populus spp.; Ulmus americana.
\end{abstract}

Regina, Saskatchewan, Canada, is a midsized Canadian city that was founded on a treeless prairie. Nearly all trees within Regina's city limits were hand-planted and are highly valued by residents. As of 2006, Regina's urban forest contained approximately 45,000 municipally owned American Elms (Ulmus americana) and 32,000 privately owned American Elms. The city is divided into 77 distinct service areas (sectors) for the purpose of urban forestry and Integrated Pest Management (IPM) operations (Figure 1). The IPM section monitors and controls pest populations within the urban forest on a sector by sector basis (Regina Urban Forest Management Strategy 2000).

The life cycle and habits of cankerworms have been known for over two centuries. In 1795, William D. Peck published The Description and History of Cankerworms (Pfadt 1985). This species, commonly known as spring cankerworm, was identified by Peck as Paleacrita vernata. A fall cankerworm (Alsophila pometria $\mathrm{L}$.) would later be identified. Cankerworms belong to the family of Geometridae in the order of Lepidoptera. Both species are widely distributed across North America. Cankerworm larval feeding occurs primarily on elm (Ulmus spp.) and also occurs on maple (Acer spp.) and other ornamental trees ( $\mathrm{La}$ France and Westwood 2006).

The common name of spring and fall cankerworms reflects the period of adult emergence. In Regina, spring cankerworm adults emerge in early spring as soon as the snow cover recedes from the base of the trees. The gravid wingless female climbs into the crown of the tree and deposits egg masses of up to 400 eggs in bark crevasses and under bark scales (Philip and Mengersen 1989). Fall cankerworm adults emerge from the soil in late September and October. The gravid wingless female of this species climbs up the tree and deposits egg masses of up to 100 eggs in bark crevasses, twigs, and other branches. The eggs of the fall cankerworm are the overwintering stage (Philip and Mengersen 1989).

The eggs of both species hatch in spring as soon as the buds begin to open. Larvae can move between trees and escape predators by descending from long, thin silk lines. This silk allows the larvae to be able to swing between differing trees (Johnson and
Lyon 1991). On maturity, the larvae "drop" on the silk lines and begin to pupate just beneath the soil surface (La France and Westwood 2006).

Two methods of control are common. The first is tree banding. A sticking agent applied to the trunk traps wingless gravid female cankerworms as they move along the trunk to deposit their eggs (Johnson and Lyon 1991). The second method is tree spraying using a registered insecticide often containing Bacillus thuringiensis kurstaki (Btk). Btk specifically targets feeding cankerworm larvae (La France and Westwood 2006). Bacillus thuringiensis is a naturally occurring bacterium found in soils and grain dust (Baum et al. 1999).

Historically, cankerworms have been a viewed by Regina's residents as a chronic nuisance to elm, maple, and ornamental tree populations in the urban forest. In reality, this pest has the potential to defoliate a significant portion of the city's urban forest in a short period of time. During the most extreme cankerworm defoliation events, ash (Fraxinus spp.) and poplar (Populus spp.) have also been entirely defoliated. The IPM section has been tasked with monitoring and controlling cankerworm populations when necessary.

For over 20 years, the IPM section monitored cankerworm populations by installing tree bands on randomly selected cityowned elm trees. Tree bands have been placed on an approximate band to tree ratio of 1:110. Sectors with higher populations of elms had a greater number of bands. As a general rule, sectors rated as requiring the greatest priority of control were those with the highest numbers of female cankerworms. If female counts in two sectors were equal, the number of male cankerworms was used as a second determining factor. High-priority sectors were also evaluated for defoliation by cankerworm larvae. Sectors would be treated with a single application of Btk in an effort to treat as many sectors as possible. On average, control operations would continue for a 4-week time period. Treatments would stop when cankerworm larvae were no longer present and had stopped feeding.

This method of setting sector priority for treatment had a number of drawbacks. First, sectors with greater numbers of 




Figure 1. City of Regina urban forestry sector map.

cankerworm bands had a greater potential for generating higher counts and would therefore be of higher priority by default. The female count would not be averaged by the number of trees surveyed within the sector; thus, tree density would not be taken into account. Second, counts were only compared relative to the survey timeframe. This meant that the IPM would only identify which sectors rated highest and which rated lowest relative to each other. It did not, however, clearly identify if tree spraying was even required. In years when there were substantively low counts, the question "Was tree spraying necessary?" could never be definitively answered.

Cankerworm action thresholds (ATs) were developed as a way to answer this question. An AT refers to the point at which an insect population density is sufficient to require control (Ball et al. 1999). This was in reaction to pressure brought by those who questioned what constituted the responsible use of pesticides (Weersink et al. 1991).

One method to aid in the identification of an AT in a managed landscape system such as a municipal urban forestry program is by establishing the aesthetic injury level (AIL). Utilization of this concept would quantify the lowest level of aesthetic injury allowable when caused by a pest population. Utilization of this concept would thereby reduce the likelihood of unnecessary control treatments (Olkowski 1974; Raupp et al. 1989).
A 1990 study established an AIL for orangestriped oakworm (Anisota senatoria) affecting oak (Quercus spp.) plantings. This study found that by establishing the AIL at $25 \%$ defoliation with a continuous monitoring program, pesticide use by volume was reduced by $80 \%$ (Coffelt and Schultz 1990).

Further study on the orangestriped oakworm then correlated the number of egg masses to diameter at breast height (dbh) with an AIL of $25 \%$ defoliation on pin oak (Quercus palustris). The study showed that there was a linear relationship between the $\mathrm{dbh}$ and the number of egg masses. As an example, findings showed that there were 9 egg masses on a tree with $25 \%$ defoliation with a mean dbh of $35.4 \mathrm{~cm}$ (14.2 in). Comparatively, on a tree with a mean dbh of $19.1 \mathrm{~cm}$ (7.6 in), there were $4.8 \mathrm{egg}$ masses on a tree with $25 \%$ defoliation (Coffelt and Schultz 1993).

A study on fall cankerworms showed that there was a strong correlation between the average number of female fall cankerworms trapped per tree to the average percent defoliation for large oak trees. This correlation was initially determined to be $\mathrm{r}=0.786$. This same study also concluded that female cankerworm counts were also more accurate in relationship to tree defoliation than were egg mass counts (Kegg 1967). With this correlation, the potential of damage caused by one cankerworm generation could be predicted by measuring the population of its predecessor. 
Sampling populations of pests have previously been an effective method in establishing an AT. Action thresholds were developed for codling moth (Cydia pomonella [L.]) in apple orchards. Baited pheromone traps were placed in plots within apple orchards. Plots with low damage resulting from insect defoliation were identified. Insect counts were then obtained from these plots. The AT was then established as $95 \%$ or greater of the counts in these plots. Once the AT was met, control activities would then start (Knight and Light 2005).

As such, tree banding should not be looked at solely as a passive control mechanism for interfering with the life cycle of cankerworms. Through use of sampling techniques, tree banding for cankerworms can also serve as an indicator for the potential for damage.

\section{MATERIALS AND METHODS}

The intent of this study was to create an AT identifying deviations from the normal density of a cankerworm population using the empiric rule. The benchmark is based on a normal population distribution in which $68 \%$ of the population will be within one standard deviation (SD) of the mean and 95\% within two SDs. The remaining $5 \%$ of the population will be greater than two SDs of the mean and this portion would be split equally between the high and low ends of the population (Medenhall 1987).

Through use of historic monitoring records, we established a mean and SD of a normal population density of cankerworms, i.e., one with little or no defoliation damage occurred to the urban forest and with no control operations used. The AT established was the high end of that population as two SDs from the mean.

The study then evaluated defoliation between urban forest sectors with populations that rated above and below the AT. Damage levels in sectors exceeding the AT but were not sprayed were compared with sectors that did not exceed the AT.

This study was conducted in three phases. Phase 1 was the establishment of the AT by application of the empiric rule. Phase 2 was the comparison of cankerworm counts for sectors relative to the AT with the highest rated sectors being selected for tree spraying activities. Phase 3 was the evaluation of the AT by assessment of sector defoliation for untreated areas that ranged above and below the AT.

\section{Phase 1: Establishing the Action Threshold}

Historic records were used to identify years in which no cankerworm spraying occurred. In each of these years, the fall female cankerworm count from the year prior and the spring female cankerworm count of the next year were identified, because these are the two cycles when egg masses are laid. The total of the female cankerworm counts (c) was identified by sector. The average number of females per tree in each sector (C) was calculated by dividing the total number of females cankerworms (c) trapped in that sector by the total number of surveyed trees for that same sector $(\mathrm{t})$.

$$
\mathrm{c} / \mathrm{t}=\mathrm{C}
$$

This calculation was conducted for each sector based on the spring and fall cycle. The AT, mean $(\mu)$, and the $\operatorname{SD}(\mathrm{s})$ of the female cankerworms per tree per sector were then calculated.

$$
\mathrm{AT}=\mu+2(\mathrm{~s})
$$

\section{Phase 2: Comparison of Sectors Relative to the Action Threshold}

A total of 404 cankerworm bands were placed on city-owned elm trees in 62 sectors, an approximate band-to-tree ratio of $1: 110$, to account for the city-owned elm tree population density. The bands were constructed by wrapping the trunk with a $20 \mathrm{~cm}$ (8 in) wide band of fiberglass insulation. The insulation was then covered with dark plastic wrap and fastened to the tree using duct tape. The sticking agent was then applied to the surface of the plastic (Figure 2).

Fall cankerworm counts were made from 15 September to 15 October 2005 with three survey cycles (one survey cycle $=404$ bands counted for cankerworms). During each count, cankerworms were removed from the tree bands. The bands were repaired and the sticking agent reapplied when necessary. On completion of each cycle, the next cycle of counts would immediately begin. Spring cankerworm counts were completed from 15 April to 15 May 2006 with three survey cycles being completed in the same manner as the fall counts.

On completion of spring and fall counts, each sector was compared against the AT. The average number of cankerworm females per tree per sector was calculated.

$$
\text { Spring \& Fall Average } q \text { per Tree }=\left(\left[c^{1}+c^{2}\right] \div 2\right) \div \mathrm{t}
$$

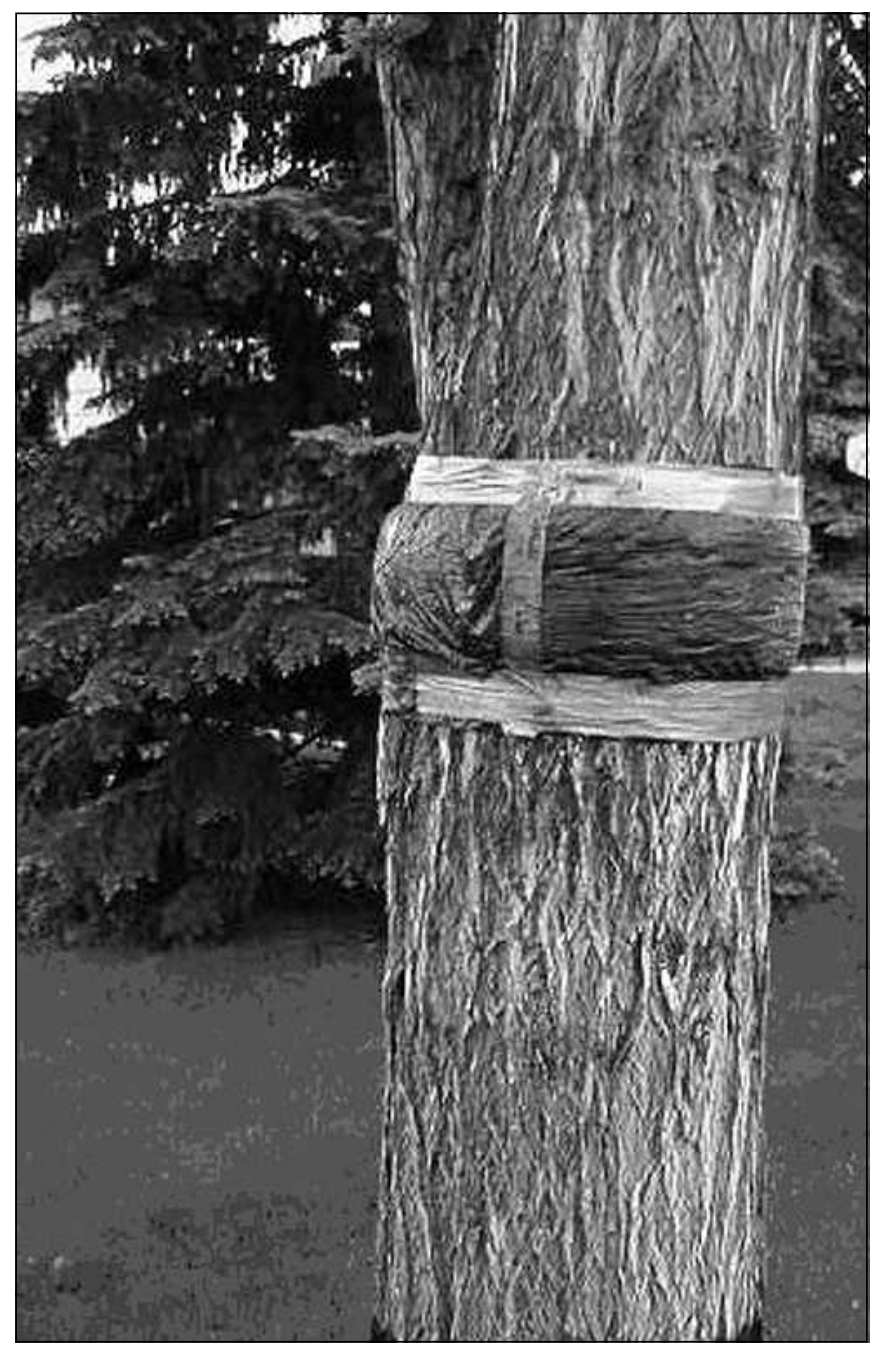

Figure 2. City of Regina cankerworm monitoring band. 
where $\left(c^{1}\right)$ is the total 2005 fall cankerworm female count, $\left(c^{2}\right)$ is the total 2006 spring cankerworm female count, and (t) is the number of tree bands monitored in the sector.

Sectors above the AT were targeted for Btk applications. Control operations began once larvae were confirmed to have hatched. Each targeted sector was sprayed as weather conditions permitted. Only one application was made. Control operations stopped when it could be confirmed that the larvae were no longer present and feeding.

\section{Phase 3: Sector Defoliation Analysis}

To determine the effectiveness of the AT, cankerworm banding sites in each sector were sampled at the end of the larval cycle. By this time, feeding damage was at its maximum. Two sites from each sector (119 in total) were randomly selected from the tree banding list 2 months before larval emergence. Sectors that were sprayed were eliminated from the comparison; only trees in untreated sectors were evaluated.

The elm tree defoliation survey was conducted from 8 June to 14 June 2006. Two different survey methods were undertaken to determine the extent of defoliation. First, the canopy of each banded tree was assessed. A visual estimate of defoliation damage as a percentage of total canopy was scored. This procedure was repeated for two additional unbanded trees to the immediate right and left of the banded tree. The ratings of the three trees were then averaged and this value was reported as the percent defoliation damage on the site.

The second method involved removing five leaves from each banded tree. The total leaf surface area and total damage area missing from each leaf was tabulated. Total leaf surface area and total area damaged was measured using $1 \mathrm{~mm}^{2}(0.001$ $\mathrm{in}^{2}$ ) graph paper. This was then calculated as percent loss of total leaf surface area. The leaves were randomly removed from the tree by the technician. In cases in which the leaves could not be reached, a small branch was removed from the canopy by a lopper. The leaves were then selected from that branch.

It should also be noted that to avoid observation bias, the technicians were deliberately uninformed to the identity of which sectors measured above and below the AT.

For each method of defoliation measurement, results for treated sectors were compared with the unsprayed sectors. To reiterate, our hypothesis was that sectors measured above the AT would have greater defoliation when compared with sectors that measured below the AT. Results were analyzed by analysis of variance (ANOVA). All calculations were completed and

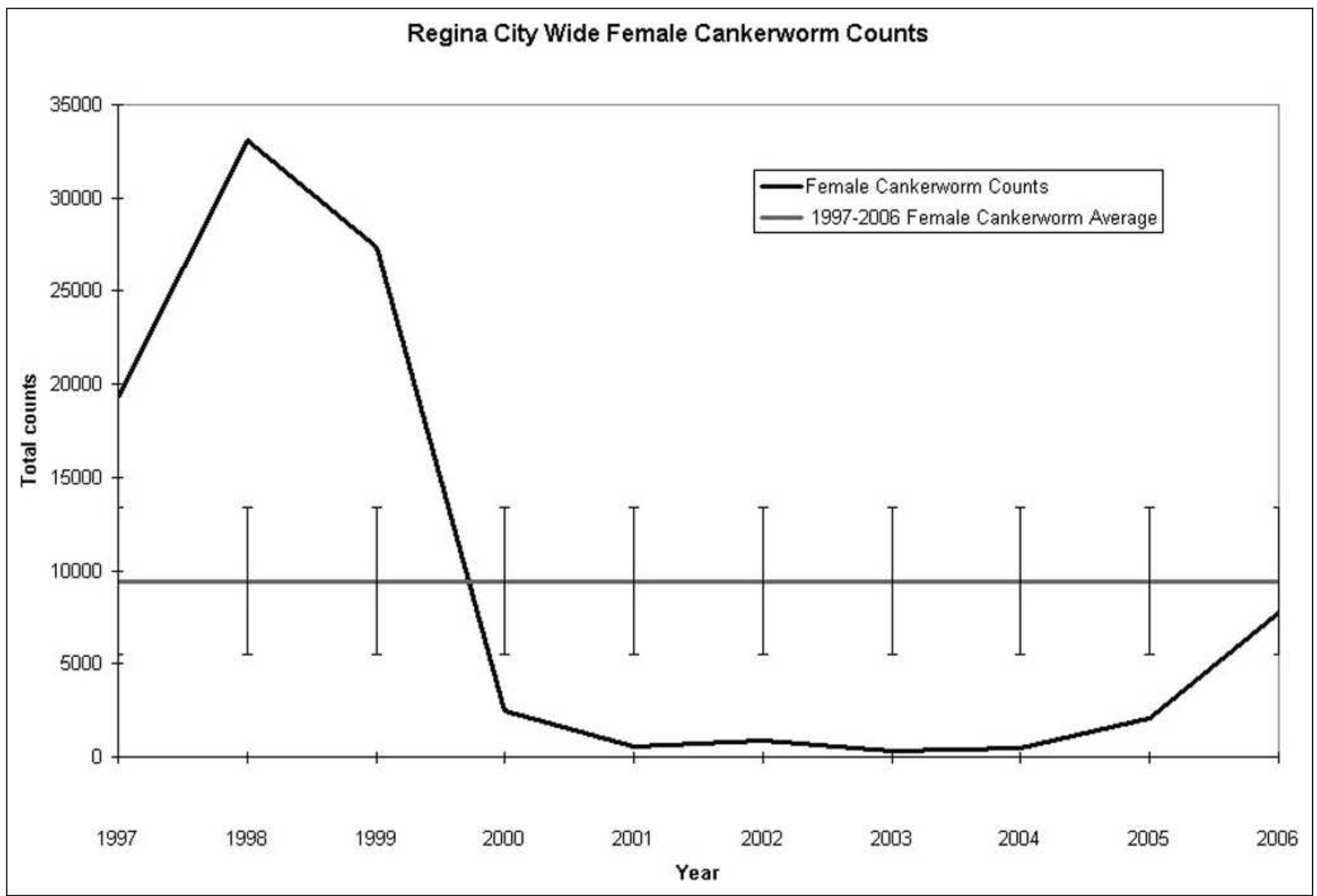

Figure 3. 1997 to 2006 Regina yearly city-wide total female cankerworm counts. Counts are total spring and fall cankerworm counts for all sectors in Regina. The 1997 to 2006 female cankerworm average is based on these total counts. An SE bar has been attached to the average. 
graphically displayed using Microsoft Excel ${ }^{\mathrm{TM}} 2003$ software (Microsoft, Redmond, WA).

\section{RESULTS}

\section{Phase 1: Establishing the Action Threshold}

The 10-year average of the yearly city wide total female cankerworm counts was 9,421 with an SE $\pm 3,940.52$. For 2001 to 2004, cankerworm counts were below this average (Figure 3) and no control treatments were applied.

Of 434 observations (62 observed sectors $\times$ seven spring and fall cankerworm counts from 2001 to 2004), the average number of females per tree was calculated to be 0.78 with a $\mathrm{SD} \pm 1.12$. Thus, the AT value was set at be 3.02 (mean +2 [SDs]).

\section{Phase 2: Comparison of Sectors Relative to the Action Threshold}

In 2006, 39 sectors exceeded the AT; 23 were below (Figure 4). Using this information, 39 sectors were identified requiring treatment. Only 10 sectors were treated as a result of weather conditions that restricted spraying activities. Approximately 12,600 trees were sprayed. In addition, sector 52 that did not exceed the AT was sprayed on 4 June 2006. The reasons for this are addressed in the "Discussion."

\section{Phase 3: Sector Defoliation Analysis}

For sector defoliation analysis, there were 96 separate observations of canopy defoliation. There were 57 observations completed in the 29 sectors that were greater than the AT and did not receive treatment. These trees had an average canopy defoliation of $23.14 \%$ with an SE \pm 1.88 . Contrastingly, there were 39 observations completed in the 22 sectors below the AT and not treated. These trees had an average canopy defoliation of $10.1 \%$ defoliated with an $\mathrm{SE} \pm 1.87$ (Figure 5). ANOVA calculations indicated significance in defoliation between sectors above and below the AT $\left(\mathrm{F}_{1,94}=22.53, \alpha=0.05, P<0.001\right)$.

For leaf defoliation analysis, there were 96 separate observations of leaf defoliation (57 separate observations for the 29 sectors above the AT; correspondingly, 39 separate observations for sectors below the AT). Percent leaf defoliation averaged $16.4 \%$ ( $\mathrm{SE}= \pm 1.36$ ) in the 29 sectors above the AT and were untreated. In the 22 untreated sectors below the AT, leaf defoliation averaged $10.6 \%$ defoliated with an SE \pm 1.32 (Figure 6). ANOVA calculations indicated significance in defoliation between sectors above and below the AT $\left(\mathrm{F}_{1,94}=8.63, \alpha=0.05\right.$, $P<0.004)$.

\section{DISCUSSION}

This study shows that there is a difference in defoliation between sectors that measured above and below an AT established on historic cankerworm counts.

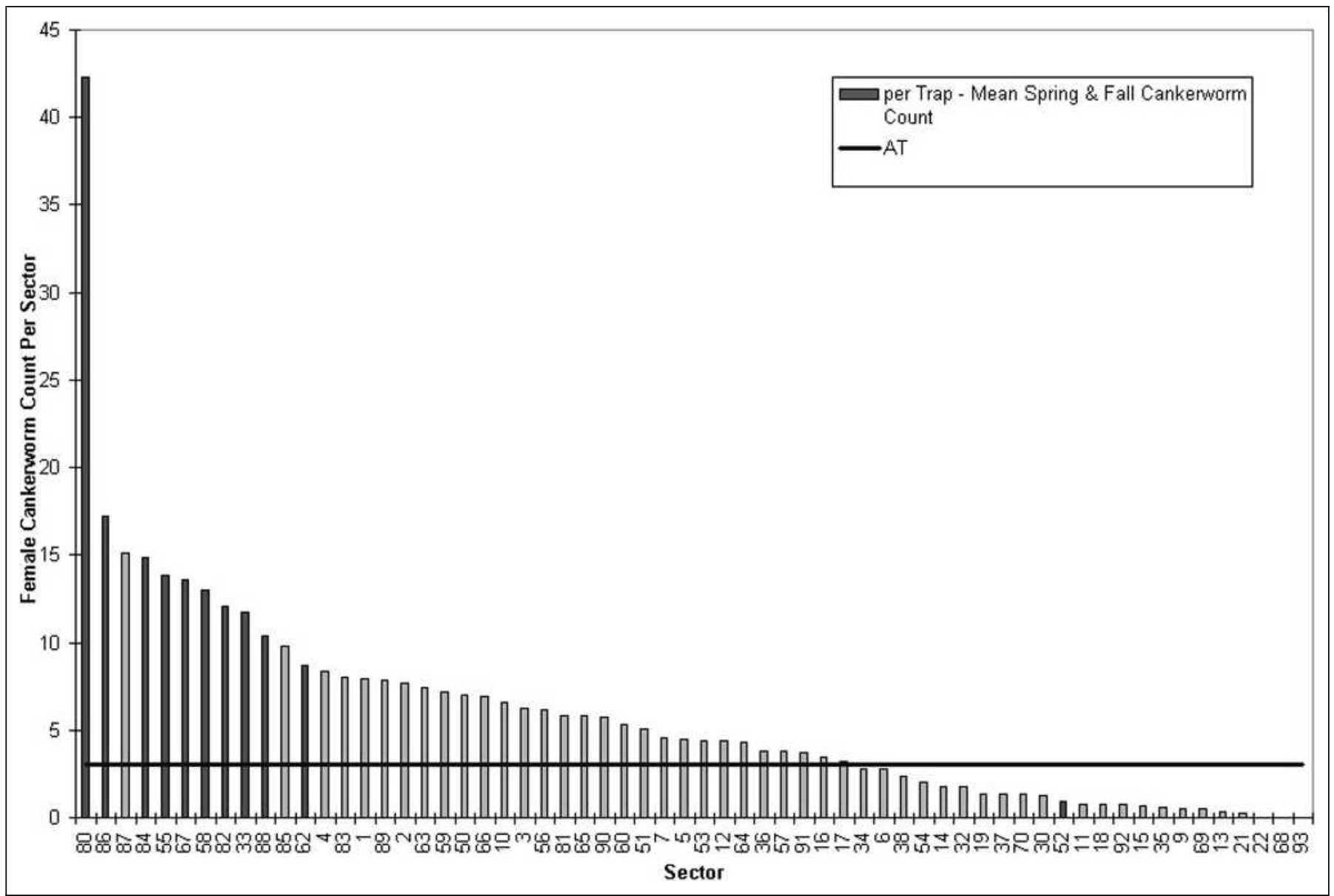

Figure 4. Mean female cankerworms per tree for each sector ordered from highest magnitude to lowest. Dark-shaded bars indicate sectors that were sprayed. Light-shaded bars indicate sectors that were not sprayed. 


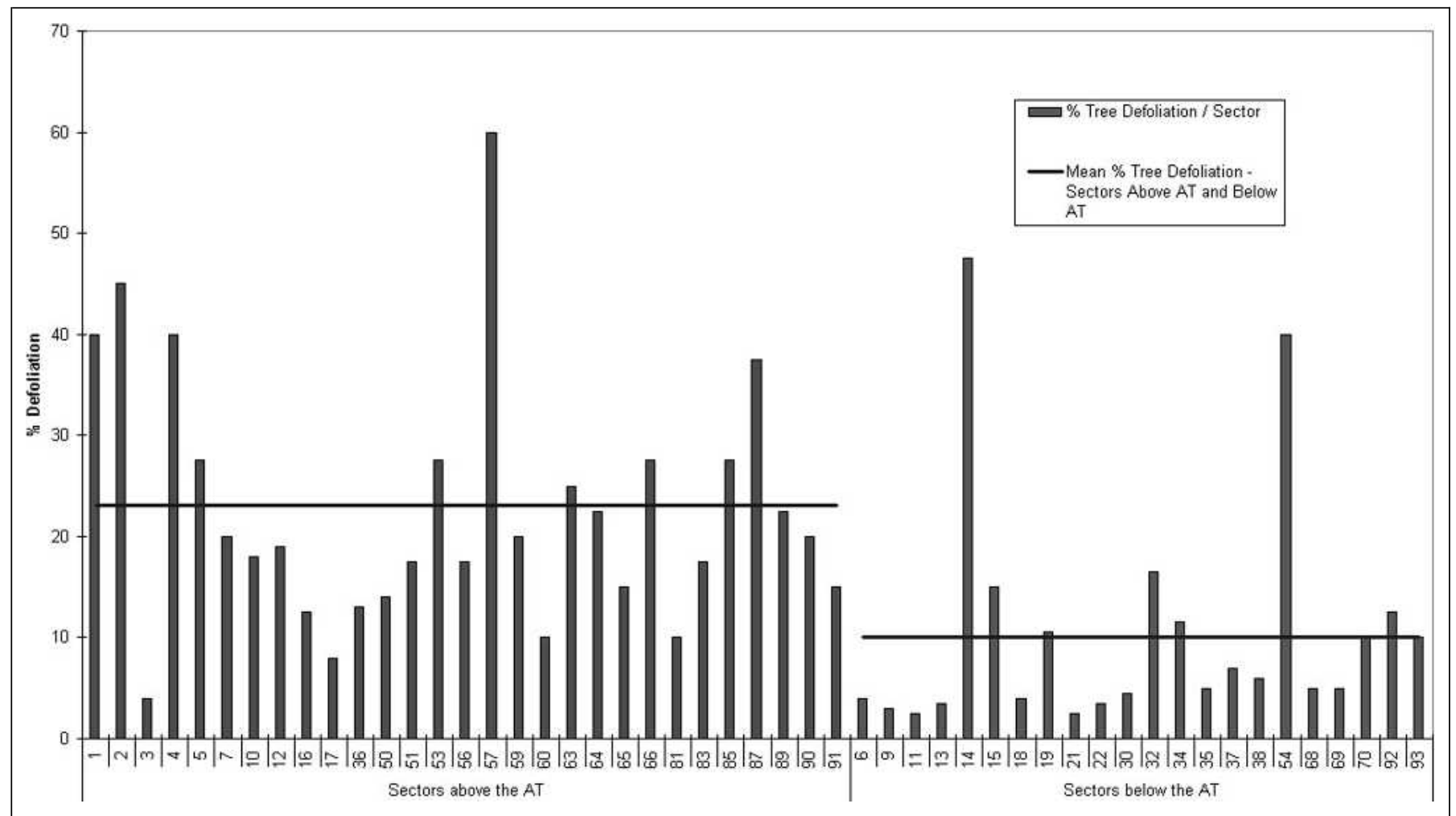

Figure 5. Percent tree canopy defoliation per sector shown with the respective means of sectors above and below the action threshold.

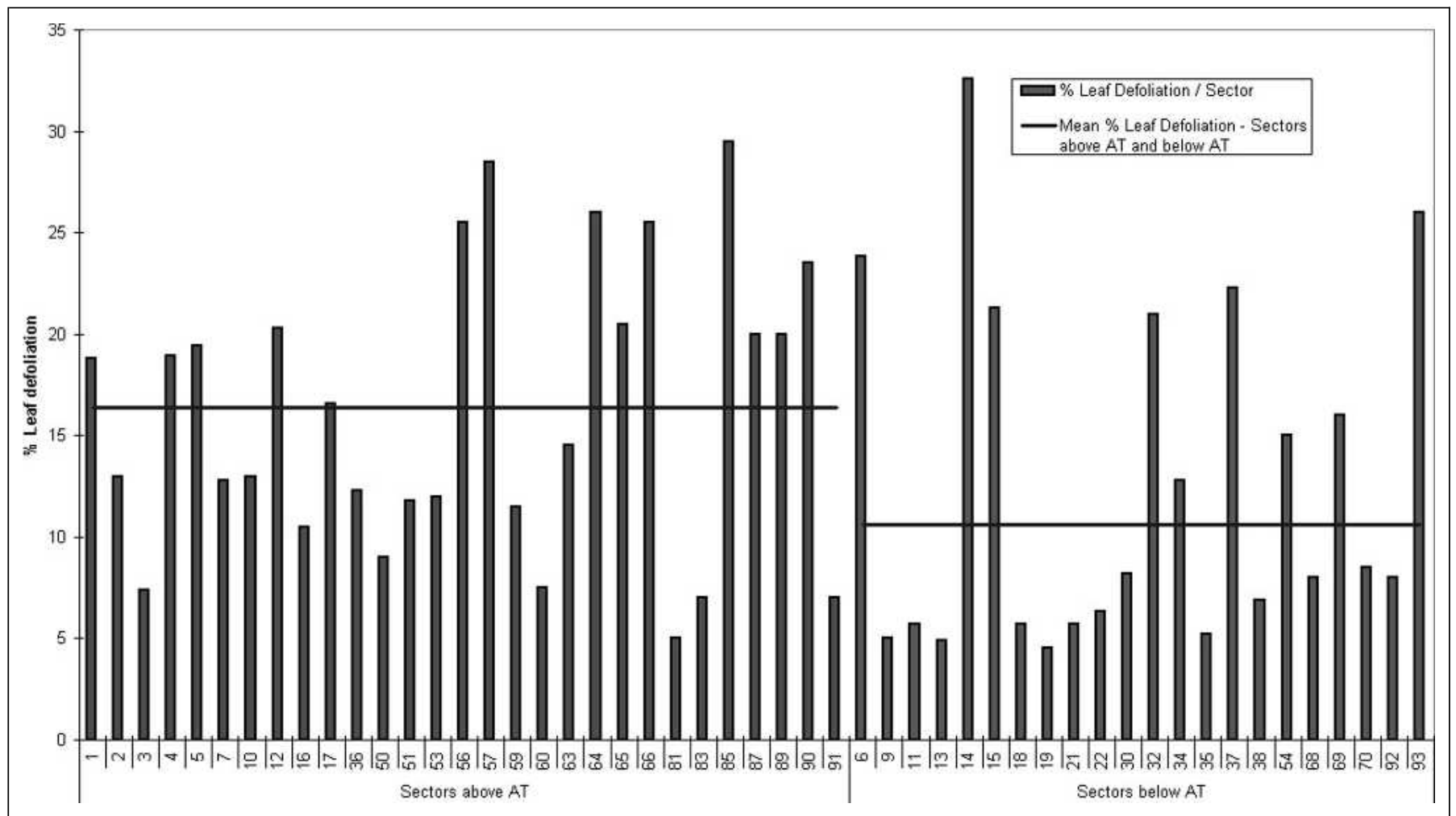

Figure 6. Percent leaf defoliation per sector shown with the respective means of sectors above and below the action threshold. 
First and foremost, public pressure for action may supersede decisions based on the AT. For example, sector 52 was treated for cankerworms although it measured below the AT. This was the result of pressure brought by residents. In this sector, College Avenue is a highly visible public space and damage from cankerworm larvae was clearly visible. College Avenue is a border street between the city of Regina and Wascana Park, which is managed solely by another agency. This sector was not included in the calculations as a result of the fact that it was considered to be a treated sector.

Second, weather influenced control treatment operations, decreasing the number of sectors that would have been sprayed. Regina experienced higher than normal precipitation, which in turn delayed spraying activities. Had weather conditions been optimal, more sectors could have been completed. For example, sectors 85 and 87 were not sprayed although they were ranked high enough to warrant treatment (Figure 4).

Third, this study was limited only to sectors that were not sprayed. We assumed that treatment reduced the amount of defoliation damage. If true, then the sectors that measured above the AT would have even greater defoliation. However, the consequences of proving this point would not likely be acceptable to the general public.

Finally, we hope by creating an AT in this manner that we can recognize the potential for a greater than normal pest population and anticipate the potential for damage to the urban forest. By doing so in a rational manner based on a historic perspective, decisions on when control operations are required can be more easily made. That said, there are limits to the city's ability to respond to cankerworm infestations as a result of the narrow window of treatment effectiveness and the availability of labor, equipment, and weather.

Acknowledgments. I thank Wade Morrow and Neil Vandendort for input and permission to use the City of Regina records for this project. I also thank Leroy Bidlo for input toward this paper. Further thanks to City of Regina IPM staff, specifically Geoff McLeod, Brendan Moat, Christopher Dowson, and Wayne Johnson for their work at gathering data relevant to this article. A final thank you to Colyn Lowenburger for review of the statistical analysis in this article.

\section{LITERATURE CITED}

Ball, J., J.E. Lloyd, and D.F. Marion. 1999. The appropriate response process (ARP) and its role in plant health care. Journal of Arboriculture 25:24-30

Baum, J.A., T.B. Johnson, and B.C. Carlton. 1999. Bacillus thuringiensis: Natural and recombinant bioinsecticide products, pp. 189-210. In Hall, F.R., and J.J. Menn (Eds.). Biopesticides: Use and Delivery. Humana Press, Totowa, NJ.

Coffelt, M.A., and P.B. Schultz. 1990. Development of an aesthetic injury level to decrease pesticide use against orange striped oakworm (Lepidoptera: Saturniidae) in an urban pest management project. Journal of Economic Entomology 83:2044-2049.

1993. Quantification of an aesthetic injury level and threshold for an urban pest management program against orangestriped oakworm (Lepidoptera: Saturniidae). Journal of Economic Entomology 86:1512-1515.

Johnson, W.T., and H.H. Lyon. 1991. Insects that Feed on Trees and Shrubs, $2^{\text {nd }}$ Ed. Cornell University Press, Hong Kong, pp. 142-143.

Kegg, J.D. 1967. Sampling techniques for predicting fall cankerworm defoliation. Journal of Economic Entomology 60:889-890.
Knight, A.R., and D.M. Light. 2005. Developing action thresholds for codling moth (Lepidoptera: Tortricidae) pear ester- and codlemonebaited traps in apple orchards treated with sex pheromone mating disruption. The Canadian Entomologist 137:739-747.

La France, K.R., and R. Westwood. 2006. An assessment of tree banding techniques to capture cankerworm defoliators of elm and ash trees in Winnipeg, Manitoba, Canada. Arboriculture and Urban Forestry 32: $10-17$.

Medenhall, W. 1987. Introduction to Probability and Statistics. $7^{\text {th }}$ Ed. PWS-Kent Publishing Co., Boston, MA. pp. 40, 347-396.

Olkowski, W. 1974. A model ecosystem management program. Proceedings Tall Timbers Management Conference on Ecological Animal Control by Habitat Management 5:103-117.

Pfadt, R.E. 1985. Insects and humans, pp. 4-5. In Pfadt, R.E. (Ed.). Fundamentals of Applied Entomology. $4^{\text {th }}$ Ed. Macmillan Publishing Co., New York, NY.

Philip, H., and E. Mengersen. 1989. Insect Pests of the Prairies. University of Alberta, Faculty of Extension. Edmonton AB. 64-65. 71 pp.

Raupp, M.J., J.A. Davidson, C.S. Koehler, C.S. Sadof, and K. Reichelderfer. 1989. Economic and aesthetic injury levels and thresholds for insect pests of ornamental plants. The Florida Entomologist 72: 403-407.

Regina Urban Forest Management Strategy. 2000. Community Services Department, City of Regina, Regina, Saskatchewan. 17, A-3 pp.

Weersink, A., W. Deen, and S. Weaver. 1991. Defining and measuring economic threshold levels. The Canadian Journal of Agricultural Economics. 39:619-625.

\section{Russell Eirich}

Entomology Research Analyst

City of Regina, Integrated Pest Management Section

PO Box 1790

2476 Victoria Avenue

Regina, Saskatchewan S4P 3C8, Canada

reirich@regina.ca

Résumé. Un seuil d'intervention est souvent établi afin de déterminer si des traitements de contrôle des populations de parasites sont requis et quand. En milieu municipal, des traitements de contrôle des insectes défoliateurs de la forêt urbaine sont typiquement établis en fonction des demandes des consommateurs, de demandes d'entretien faites pour des lieux publics hautement visibles, pour des fins économiques ou pour des dommages causés par des insectes. En 2006, la Section de gestion intégrée des insectes et maladies de la Ville de Regina a créé une nouvelle méthode pour établir le seuil d'intervention pour le contrôle des vers d'arpenteuse en déterminant si le décompte des femelles d'arpenteuse (Paleacrita vernata Peck and Alsophila pometria L.) était supérieur à 95\% du niveau dit normal de population, et ce en se basant sur des données historiques.

Zusammenfassung. Ein Schwellenwert ist oft etabliert, um festzulegen, ob und wann Kontrollbehandlungen beim Auftreten von Krankheiten erforderlich sind. Auf kommunaler Ebene sind Kontrollbehandlungen für entlaubende Insekten in den urbanen Wäldern typischerweise in Resonanz mit der Kundenanforderung, Pflegeanforderungen von öffentlich sichtbaren kommunalen Bereichen, ökonomischen Anforderungen und den aktuellen Insektenschäden zu bestimmen. Die zuständige Stelle für Integrierten Pflanzenschutz in Regina entwickelte eine neue Methode, einen Schwellenwert für die Kontrolle von SpannerRaupen festzulegen, wenn die Anzahl der weiblichen Spanner-Raupen 
(Paleacrita vernata Peck and Alsophila pometria L.) mehr als $95 \%$ einer identifizierten „normalen“ Population, basierend auf historischen Aufzeichnungen, beträgt.

Resumen. Con frecuencia se establece una aproximación con el fin de determinar si y cuando los tratamientos de control son requeridos para las poblaciones de plagas. En ambientes municipales, los tratamientos de control para insectos defoliadores en bosques urbanos son determinados típicamente en respuesta a los requerimientos del cliente, demandas de mantenimiento de espacios públicos municipales altamente visibles, requerimientos económicos y daño real del insecto. En 2006, la Sección de Manejo Integrado de Plagas de la Ciudad de Regina creó un nuevo método de establecimiento de una acción para el control del gusano canceroso determinando si los conteos de monitoreo para gusanos hembras (Paleacrita vernata Peck y Alsophila pometria L.) fueron mayores al 95\% de una población "normal" identificada con base en registros históricos. 